\title{
Incidence of the fimbriate phase amongst Escherichia coli isolated from urinary infections
}

\author{
A. C. BUCK \\ From the Department of Bacteriology, Wright-Fleming Institute, St. Mary's \\ Hospital Medical School, London
}

SYNOPSIS The proportion of fimbriate strains amongst Escherichia coli freshly isolated from infected urines did not differ significantly from the proportion amongst commensal Esch. coli isolated from the bowel and from non-infected urines. It is concluded that fimbriae play no major role in the pathogenesis of Esch. coli urinary infections.

Most infections of the kidneys and bladder are caused by organisms that have reached these organs by ascending the lumen of the urinary tract (Brumfitt and Percival, 1964). Initially most of the bacteria will be present in the urine and will be washed away when it is passed, but any that are attached to the mucosal surface will be more likely to remain behind and it is these that might be expected to cause infections.

The most commonly isolated urinary pathogen is Escherichia coli. These bacteria, like other members of the Enterobacteriaceae, can exist in two forms: a fimbriate form capable of adhering to surfaces and agglutinating red cells in vitro and a non-fimbriate form lacking these properties. In some strains these two phases are interchangeable, depending on conditions of growth (Duguid, 1964; Duguid, Smith, Dempster, and Edmunds, 1955; Brinton, 1959).

It was thought of interest to examine Esch. coli isolated from urinary infections to see whether they were more commonly fimbriate than corresponding commensals isolated from the rectum or as contaminants in the urine.

MATERIALS AND METHODS

Escherichia coli were identified by their colonial appearance on blood and MacConkey agar, the ability to ferment lactose, and the production of indole in peptone water. For most agglutination tests organisms were grown in nutrient broth (Oxoid) and on nutrient agar made from the broth by adding $1.5 \%$ New Zealand agar.

Received for publication 1 September 1966.
In some tests blood agar was used which contained $10 \%$ horse blood.

All cultures were incubated at $37^{\circ} \mathrm{C}$. The non-fimbriate phase of the variable strains was selected by 10 serial aerobic subcultures on nutrient agar; the corresponding fimbriate phase was obtained by 10 serial subcultures in nutrient broth, incubated without agitation.

The ability of Esch. coli to agglutinate horse red cells in saline, but not in the presence of $0.5 \% \mathrm{D}$-mannose, was taken to indicate that the strain was fimbriate (Duguid and Gillies, 1957). Organisms from solid and liquid media were suspended in normal saline to give a concentration of between $1 \times 10^{10}$ and $5 \times 10^{10}$ particles per millilitre. One drop of the suspension of organisms was added to each of three tubes $\left(3 \mathrm{in} . \times \frac{3}{8}\right.$ in.). To the first tube was added one drop of $5 \%$ horse cells in normal saline; to the second tube one drop of horse cells in normal saline plus $1 \% \mathrm{D}$-mannose and to the third one drop of normal saline. The three tubes were shaken in a water bath at $4^{\circ} \mathrm{C}$. for five minutes and then left to stand for a further five minutes, after which the degree of red cell agglutination was determined by naked-eye examination.

RESULTS

FIFTEEN STOCK STRAINS OF ESCHERICHIA COLI These strains had been originally isolated from cases of primary urinary infection and included most of the common ' $O$ ' groups found in infected urines.

Six strains were permanently fimbriate, one strain was permanently non-fimbriate, and eight strains were variable depending on the conditions of growth. 
FRESHLY ISOLATED STRAINS OF Escherichia coli The frequency of variable strains amongst the stock cultures examined meant that it was not possible to determine how many strains were fimbriate when they were causing the infection. To overcome this difficulty, 25 infected urines were cultured in parallel on blood agar and in nutrient broth. The solid media would favour the growth of non-fimbriate organisms, while the liquid media would favour the growth of the fimbriate variants.

Each pair of cultures was examined for the presence of fimbriae. In every case except one, both members of a pair were in the same phase. It was therefore felt that a reasonably accurate picture of the incidence of the fimbriate phase in infected urine could be obtained by studying the organisms isolated on the initial blood agar plates.

A further 25 strains of Esch. coli from infected urines were examined and compared with organisms of the same biotype isolated from normal stools and from non-infected urines, i.e., urines with total bacterial counts of less than 10,000 organisms per millilitre. The stool specimens were obtained from

\section{TABLE I}

FREQUENCY OF FIMBRIATE STRAINS AMONGST FRESHLY ISOLATED Escherichia coli FROM VARIOUS SOURCES

Source of Esch. coli No. of Strains Percentage Fimbriate

Infected urines

( $>10^{5}$ organisms $/ \mathrm{ml}$.)

a) With raised

urinary white

cell count

b) With normal

urinary white cell count

Non-infected urines

( $<10^{4}$ organisms/ml.)

Normal stools and

rectal swabs different subjects from those furnishing the urine samples.

The distribution of fimbriate organisms in the three groups is shown in Table I. No significant difference was observed.

\section{DISCUSSION}

The failure to find significantly more fimbriate strains amongst strains of Esch. coli isolated as contaminants from the urine than among those isolated from stools must mean that fimbrial adhesion plays little part in an organism's ability to colonize the urethra. The fact that fimbriation is no more common among strains causing infections than those isolated as contaminants presumably means fimbriae do not play an important part in the pathogenesis of urinary infections. A similar conclusion has been drawn regarding the importance of fimbriae in the production of disease by enteropathogenic Esch. coli (Duguid, 1964).

A more precise determination of fimbriation can be made by electron microscopy, but it was felt that these results obtained using horse red cell agglutination as an index of the presence of fimbriae did not justify the more definitive study.

I am grateful to Professor R. E. O. Williams for his help and advice and to Dr. W. Brumfitt for supplying the stock strains of Esch. coli.

\section{REFERENCES}

Brinton, C. C., Jr. (1959). Nature (Lond.), 183, 782.

Brumfitt, W., and Percival, A. (1964). J. clin. Path., 17, 482.

Duguid, J. P. (1964). Rev. lat.-amer. Microbiol., 7, suppls. 13-14, 1.

, Smith, I. W., Dempster, G., and Edmunds, P. N. (1955). J. Path. Bact., 70, 335.

—, and Gillies, R. R. (1957). Ibid., 74, 397. 